\title{
Review of sub-Saharan African gravel roads management system: Tanzanian case study
}

\author{
R. R. Mwaipungu \& D. Allopi \\ Department of Civil Engineering and Surveying, \\ Durban University of Technology, South Africa
}

\begin{abstract}
The construction of new networks of gravel roads needed by sub-Sahara Africa will eventually come to completion. Furthermore, many of the gravel roads constructed or rehabilitated between 2005 and 2008 have come to the end of their design lives and during their life cycle, difficulties were experienced in getting required funds for maintenance. What is becoming apparent to the governments and road agencies of sub-Sahara Africa is the urge to conserve, as national asset, the gravel roads network, through the use of operational road management systems.

Based on the above mentioned desire, the sub-Saharan African countries, including Tanzania, are exploring ways of strengthening the management of roads transport infrastructure.

Towards that end Tanzania have two organisations responsible for managing its road networks, namely Tanzania Road Agency (TANROADS) and Local Government Authority (LGA)'s district engineer's office. TANROADS is responsible for the management of trunk and regional road networks, while LGAs are responsible for the management of districts road networks.

Each of these road agencies uses its own road management system. TANROADS uses Road Maintenance Management Systems (RMMS), and LGA uses District Roads Management Systems (DROMAS). Both these systems have been developed with experts and financial assistance from foreign countries, with involvement of local experts at ministerial or top managerial levels. This paper discusses and points out factors affecting the efficiency and effectiveness of these systems in gravel road management in comparison with those in the developed world. It is expected that ironing out those aspects of management
\end{abstract}


affecting effective and efficient conservation of gravel roads will improve further their performance.

Keywords: gravel roads, pavement management system, effective, monitoring, performance, infrastructure, road mentor, inventory, road condition survey, conservation.

\section{Introduction}

Increased demands for economic efficiency in the use of scarce public funds for conserving gravel roads networks has engendered a need for roads agencies in sub-Sahara Africa to resort to the use of appropriately designed gravel road management system. Such systems offer the necessary flexibility to undertake various aspects of road infrastructure asset management in a structured, comprehensive and cost-effective manner (Pinard [1]).

For the scarce funds to be spent wisely, a mechanism to determine deterioration and treatments must be objective, robust, and consistent, so that the needs on one part of the network can be accurately compared with those on other parts (Oliver [2]). Hence, the main objectives of establishing the computerised RMMS are to optimise the use of limited funds available for maintenance works; to have a systematic approach and planning of road maintenance works programmes and to reduce the entire transport costs through proper and timely maintenance works.

Tanzania has two organisations responsible with managing its road networks, namely TANROADS and LGA's district engineer's office. Each one uses its own computerised road management system. TANROADS uses RMMS, and LGA uses DROMAS. Both these systems have been developed with experts and financial assistance from foreign countries, with involvement of local experts at ministerial or top managerial levels. This paper discuss and point out factors affecting the efficiency and effectiveness of these systems in gravel roads management in comparison with those in the developed world. It is expected that ironing out those aspects of management affecting effective and efficient conservation of gravel roads will improve further their performance.

\subsection{Scope and objectives}

This paper looks at the Tanzania Pavement Management Systems (PMS) operation as a typical case of the PMS in use in sub-Sahara Africa. The paper compares the system with those in developed countries in terms of data collection method and analysis, rating of pavement condition and software employed in the management of unsealed road networks. By pointing the weakness of the system the author expects to stimulate the changes required to make the system works better in conserving the roads network under question.

The objectives of this paper are to: (1) stimulate attitude changes in maintaining pavements that is from a reactive to a proactive approach, (2) improve further the management of gravel roads, and (3) make the Tanzania PMS transparent and exposed to critics. 
In this paper, the term PMS refers to management of gravel wearing course, or unbound layers on top of a formation level making up a structure of gravel surfaced road. One has to note in advance, that the extent of information gathered and the terms used to describe PMS operations vary with the country in question.

\section{Pavement management systems}

\subsection{General}

A PMS is a systematic method of information collection, analysis and decision making, designed to permit the optimisation of resources for the maintenance, rehabilitation and reconstruction of pavements (Underwood [3]). According to Shahin [4], a pavement management system provides a systematic, consistent method for selecting maintenance \& rehabilitation needs, determining priorities and the optimal time for repair by predicting future pavement condition.

One of the key features of pavement management is the comparison of pavement needs within the funding constraints (TRH 22 [5]).

\subsection{Fundamentals of PMS}

According to Oliver [2], fundamentals of PMS are; Inventory data, Condition data, Maintenance Standards, Economic analysis, Budgetary analysis, Programming and Works control and feedback. Underwood [3] put PMS in three modules, namely a database, an analysis and a reporting module. This paper will discuss the database and analysis modules. The database module contains all the fundamentals of PMS as listed under [2].

\subsubsection{PMS database module}

The database module includes (1) Road Reference System, (2) Road Inventory, (3) Road condition, and (4) Treatment types and costs. The first three are briefly described below:-

1. Road Reference System The road reference system is required to tie all the information stored in the database to fixed points in the road system. It comprises a set of links, described on a map by start and finish nodes. The nodes are permanent physical features in the road network, such as culverts, bridge abutments, and intersections.

2. Road Inventory The road inventory is a collection of information generated on the basis of data obtained on the roads that make up a network. According to Tanzania Prime Minister's office responsible for Regional Administration and Local Government (PRORALG [6]), data collected shall include the particular specification and characteristics of a road, its condition, its volume of traffic, and the climatic condition in the area where it is located, while Oliver [2], asserts that the information gathered should be limited to the location, nature, age, purpose and provider of each road component. The quality and quantity of information collected during road inventory differ with the organisation doing the exercise. 
3. Condition survey A condition survey is usually based on visual inspection to register all conspicuous defects of pavement, shoulders, ditches, culverts, slopes and road furniture (Schliessler and Alberto [7]).

Data on the road condition provides the basis for (1) identifying road sections with poor condition and/or performance; (2) selecting maintenance, (3) rehabilitation and reconstruction actions; and (4) establishing priorities. The nature and extent of road condition data to be collected will depend on the importance of the road, the type of analysis to be carried out and the resources available.

Condition survey in developed countries is mostly mechanised, the philosophy behind the exercise is to minimise disruption to the travelling public. From European experience, the road condition has to be assessed by experienced engineers and reported on a standard form to ensure, as far as possible, uniformity of approach and reliable results, which are above suspicion.

(a) Rating of unsealed road condition PRORALG [6] uses three to four ratings, namely good, fair, bad and poor conditions. Where three criteria are used, the 'bad condition' is dropped. Road Mentor uses five criteria. A typical rating system for an unsealed pavement that uses five criteria is shown in Table 1 (Underwood [3]).

Table 1: $\quad$ Rating system for unsealed roads.

\begin{tabular}{|c|c|}
\hline Rating Level & Extent and Severity of Distress \\
\hline Very good & No signs of distress \\
\hline Good & Some minor signs of distress \\
\hline Fair & $\begin{array}{c}\text { Moderate distress, indicating the need for routine } \\
\text { maintenance or a re-gravelling }\end{array}$ \\
\hline Poor & More severe distress, indicating the need for a re-gravelling \\
\hline Very poor & Failed surface, requiring full reconstruction \\
\hline
\end{tabular}

(b) Frequency of condition survey Condition surveys for gravel pavements should be based on the knowledge that its components deteriorate rapidly and that, the frequency selected should reflect the dynamic changes on the gravel roads in question. In general, the unsealed road condition survey has to be conducted twice or three times per year, to enable effective monitoring of changes in pavement condition.

\subsubsection{PMS analysis module}

PMS analysis can vary from selecting the appropriate types of treatment for individual sections of road, assigning rankings, to relatively complex considerations of optimising the distribution of funds and works programs.

2.2.2.1 Selection of appropriate type of treatment In order to select the appropriate type of treatment for an individual section of road, it is necessary to convert the pavement condition data for the section, by means of a suitable scoring system, to a single pavement condition rating. In this instance, less serious defects are assigned values between 0 and 5, and more serious ones 
values between 0 and 10. A value of 0 indicates that the pavement is free from that particular defect, while a high value indicates a serious problem. The individual defect values are added together and subtracted from 100 to give the pavement condition rating. The appropriate form of treatment can then be selected, depending on the rating. For example, a rating of 90 to $100 \mathrm{might}$ indicate that no work is required; a rating of 70 to 90 might indicate that a grading is required, and a rating of less than 70 might indicate the need of regravelling (Underwood [3]).

According to Shahin [4], the unsealed road Pavement Condition Index (PCI) procedure was developed by the U.S. Army Cold Regions Research and Engineering Laboratory. In this procedure, the results of unsealed road condition survey are used to calculate the PCI. The PCI can be calculated manually, with a PCI computer program, or by entering the distress information into the Micro PAVER database. The PCI calculation is based on the deduct values weighing factors from 0 to 100 that indicates the impact each distress has on the pavement condition. A deduct value of 0 indicates that a distress has no effect on pavement performance, whereas a value of 100 indicates an extremely serious distress.

2.2.2.2 Ranking of preferred treatments In order to rank preferred treatments on various sections, projects may be listed within each treatment type category based on the individual ratings. However, at the same time, desirable routine and preventive maintenance on the best roads must not be neglected. This can be achieved by adopting some over-riding strategies for this type of work.

2.2.2.3 Use of optimisation techniques Once one has the knowledge of pavement performance over time, computer-based techniques may be used to assist in optimising the distributions of funds or programs of works. Typically, pavement performance can be expressed in terms of the expected change in a selected condition indicator with time such as gravel loss.

\section{The overview of Tanzania road management systems}

\subsection{General}

It can be noted in Table 2 that Tanzania has a total road network of $91,049 \mathrm{~km}$. The percentage of sealed roads is 7.3 , while that of unsealed roads is 92.7 .

Table 2: $\quad$ Category of road network in Tanzania.

\begin{tabular}{|c|c|c|c|}
\hline Category & Sealed $(\mathrm{km})$ & Unsealed $(\mathrm{km})$ & Total $(\mathrm{km})$ \\
\hline Trunk Roads & 5,150 & 7,636 & 12,786 \\
\hline $\begin{array}{c}\text { Regional } \\
\text { Roads }\end{array}$ & 722 & 19,504 & 20,226 \\
\hline District Roads & 0 & 29,337 & 29,337 \\
\hline Feeder Roads & 0 & 22,703 & 22,703 \\
\hline Urban Roads & 790 & 5,207 & 5,997 \\
\hline TOTAL & 6,662 & 84,387 & 91,049 \\
\hline
\end{tabular}

Source: TANROADS 2009/2010 report and PMORALG 2010/2011 plan [8]. 
According to Tanzania road classification Act of 2007, these roads are classified into category A and B. Roads classified into category A are national roads and fall under the jurisdiction of TANROADS. Category B is district roads which fall under the jurisdiction of the Local Government road network.

Category $\mathrm{A}$ is further classified into trunk and regional roads, while in category B there are district, urban, and feeder roads, as shown in Table 2.

\subsection{Local government road network}

The PRORALG has a general responsibility of coordinating the management of all road network classified as district roads and community roads.

District roads (DRs) fall under the responsibility of the district engineer office, who works under the district executive director.

\subsubsection{PRORALG road management system}

The PRORALG has a system in place for managing the roads network under Local Government Authority known as District Roads Management System (DROMAS). DROMAS is a computer operated software package, which has been developed to prioritise district roads, identify the core network and determine the resource requirements necessary for its conservation. DROMAS is designed to facilitate effective planning of rehabilitation and maintenance works on district roads throughout the country. The planning process includes the inventory data and condition survey of district roads.

\subsubsection{Annual District Road Inventory and Condition Survey (ADRICS)}

ADRICS is a system of collecting data manually to be used in running DROMAS. The system guides the district engineer in collecting inventory and road condition data. The inventory data recorded are: (i) the location and geometry of the road, (ii) drainage condition and drainage structures, (iii) type of soils, (iv) climate, (v) traffic, (vi) population served, (vii) maintenance history of pavement, (viii) proximity to suitable pavement materials.

A condition survey is done with the objectives of capturing the current condition of the road in terms of pavement surface, shoulder and drainage systems.

ADRICS information is recorded on site on the pre-printed form.

3.2.2.1 ADRICS pre-printed data collecting forms ADRICS uses three different pre-printed forms to collect road inventory and condition data, namely form A, B and C. Form A, is used to collect road section inventory and conditions, it is mainly an assessment form. Form B, is used to assess and update the district road structures inventory and condition. Form C, is for Ward inventory. Form $\mathrm{C}$ provides a known population of the ward as an indicator of the population which is being served by the road. The form provides preferences and priorities of the Ward in accessing the district roads, and community access road links, feeding into the district roads. The form assists in identifying the core district road network. 
3.2.2.2 The ADRICS procedure Following is a brief procedure of ADRICS: Civil Engineers (CE) and Road Inspectors (RI) in the District Engineers office drive through the entire district road network and fills forms $\mathrm{A}$ and $\mathrm{B}$ through a detailed survey of each and every one of the district road within the network. At the same time. CE and RI arrange meetings with all Wards in the district in order to fill form $\mathrm{C}$.

\subsubsection{DROMAS output}

Through the data provided by form "A", DROMAS is able to classify the individual sections of a distinct road link as part of the core or non-core network.

The software can also identify their level of maintainability whether or not a bottle neck exists. In the case of bottle neck, the software identifies the prioritization of any spot improvement and/or rehabilitation works required.

DROMAS uses data from form $\mathrm{C}$, to calculate the population served per road link, so as to determine the level of prioritization of each of the district road.

\subsubsection{Maintenance condition index (MCI)}

The maintenance condition index (MCI) is calculated by DROMAS from the data of the current condition of the gravel road. The output enables the civil engineers to make decisions of which roads should be or should not be maintained.

The MCI uses values ranging from 1 which indicate the road condition is good, to 4 which is bad/poor condition. A cut-off value of MCI 2.5 is being used, whereby any road with a value less than 2.5 is considered to be maintainable and above a value of 2.5 the road is considered to be not routinely maintainable. The road automatically reverts to the list of non-maintainable roads requiring interventions including spot repairs and/or rehabilitation.

3.2.4.1 Rehabilitation DROMAS identifies those DRs determined to be not maintainable with MCI greater than 2.5 and creates a separate list of such roads.

DROMAS determines the priority of those roads taking into account, (1) traffic levels and composition, (2) the population served, and (3) the cost of spot repairs and/or rehabilitation works. Priority is given to those roads demonstrating the best cost-effectiveness.

\subsubsection{Costs of rehabilitation and maintenance works}

For all relevant district roads maintenance, spot repairs and rehabilitation works items, Global unit rates have been established which reflect current work practice and costs of inputs. Following the inputs of ADRICS data and the Global unit rate cost defaults, DROMAS automatically provides the budget requirements reports for district roads maintenance and spot repair/rehabilitation works. These reports are dis-aggregated to detail individual funding needs with time frame selected as required.

These reports allow the Civil Engineers office and theirs staff to prepare (1) annual district road maintenance and rehabilitation programmes and work plans, (2) Three year rolling plans for all district road conservation and development works, and (3) Longer term work plans including District Road Development Plans (DRDPs). 


\subsection{TANROADS road maintenance management system (RMMS)}

\subsubsection{Background}

The then Ministry of Works, now Ministry of Infrastructure Development, first sought to develop a RMMS in the early 1990s with assistance from United Kingdom's Department for International Development (DFID). This was achieved by utilising and adapting the Road Mentor System originally developed by Jonathan Kemp Consultants and now owned by the Transport Research Laboratory (TRL) (Katula and Toole [9]).

\subsubsection{RMMS scope and models}

The RMMS is a database system which provides a repository for information on the road network administered and managed by TANROADS and provides TANROADS with a series of modules which can support the decision making within road maintenance. The RRMS is building on Road Mentor 5.

The core part of the RMMS is the database which stores information on the road network. The system includes features for manual and digital input of fresh inventory and conditions data into the database. When the database has been updated, the data can be used to estimate maintenance needs, including needs for routine and recurrent maintenance spot improvement and periodic maintenance.

The data in the database can be viewed and presented in the integrated GIS. GeoGIS is used for data viewing on the screen, while ArcView/MapInfo is used for map printouts and specialised maps. The RMMS comprise of four modules, namely routine/recurrent maintenance, periodic maintenance, budget split and contract monitoring modules, briefly described below.

3.3.2.1 Routine/Recurrent Maintenance Module (RRM) The objectives of RRM module are to: (i) estimate needs of RRM works for one year, and (ii) prioritise the estimated needs under budget constraints.

The RRM model is estimating the needs over 1 year for routine and recurrent maintenance for sealed and unsealed roads. The model estimates the routine and recurrent maintenance needs using a series of frequency and quantity tables, which link the information in the road database with maintenance needs. These needs are estimated for each sub-link, but aggregated for each link.

The RRM includes a model for prioritising the needs under budget constraints. This model is based on road element priorities, maintenance levels and traffic.

The model ensures that most roads would receive maintenance even under severe budget constraints, though not to full standard.

3.3.2.2 Periodic Maintenance Module (PM) The objectives of PM module are to: (i) estimate needs for periodic maintenance and spot improvements for a period of one year, and (ii) prioritise the works developed under budget constraints.

The road network is divided into homogenous section based on variation in traffic, inventory, and condition. For each homogeneous section the needs for periodic maintenance and spot improvements are estimated using treatment matrices. 
Different matrices are applied for unconstrained and constrained budget scenarios respectively. This is to ensure that under budget constraints not only the list of projects are shortened, but also the type of works are scaled down.

The PM includes a model for prioritising the needs under budget constraints. The prioritisation is based on a multi-criteria analysis (MCA) approach using the following parameters (i) AADT/unit costs (as a surrogate for economic feasibility) (ii) access to social services; (iii) network connectivity; (iv) population along the link; (v) access to production centres; (vi) road classification, and (vii) access to tourist centres. An MCA score is given for each maintenance project.

3.3.2.3 Budget Split Module (BSM) The objectives of the BSM are to: (i) accumulate the maintenance needs and types across all regions, (ii) analyse the consequences of budget allocations in terms of distributions between the regions and maintenance types.

The model accumulates all the needs for routine and recurrent maintenance, spot improvements and periodic maintenance across all regions and road classes.

This can be used to report on the distribution needs between regions and work types. When given a budget, the BSM will prioritise the needs to meet the given budget constraints.

3.3.2.4 Contract Monitoring Module (CMM) The objectives of the CMM are to (i) enter contract packages into the system, (ii) monitor and report on the implementation of contracts, and (iii) provides simple statistics on the contracts implemented

\subsubsection{HDM-4 analysis}

The RRMs prepared input files - a road network matrix based on the outcome of the homogenous sectioning process - are uploaded to the HDM-4 (version 2) for analysis.

The model produces multi-year maintenance programme and strategic expenditure maintenance plan. Under budget constraints, the HDM-4 system is able to prepare a maintenance programme meeting the given budget level using different objective functions.

The model strategic analysis can be run under a range of alternative budget scenarios, and the consequences to the road network can be analysed.

\section{Discussions on the PRORALG, TANROADS and developed world RMS}

Despite the uses of RMS the average condition of gravel road network in Tanzania is bad, which calls for re-examining the effectiveness of the RMS employed.

The PRORALG method of prioritising road works is partly influenced by Ward leaders and partly by the District Engineers office staff opinions. The method is purely subjective regardless of the form used to collect the data.

The parameters considered during the exercise of road condition assessment are as shown in Table 3. 
Table 3: $\quad$ Road - link section condition assessment factors.

\begin{tabular}{|c|c|c|c|c|c|}
\hline S/No. & Parameter & \multicolumn{4}{|c|}{ Assessment Criteria } \\
\hline 1 & Surface type & \multicolumn{2}{|c|}{$\begin{array}{l}\text { Surfaced within } 5 \text { years } \\
\text { ( Gravel Road) }\end{array}$} & \multicolumn{2}{|c|}{$\begin{array}{c}\text { Not surfaced within } \\
5 \text { years } \\
\text { ( Earth Road })\end{array}$} \\
\hline 2 & $\begin{array}{l}\text { Surface } \\
\text { Materials } \\
\text { Rates of } \\
\text { Wearing }\end{array}$ & $\begin{array}{l}\text { Good } \\
\text { (wears } \\
\text { slowly) }\end{array}$ & $\begin{array}{c}\text { Fair } \\
\text { (wears } \\
\text { steadily) }\end{array}$ & (damag & $\begin{array}{l}\text { or } \\
\text { quickly) }\end{array}$ \\
\hline 3 & $\begin{array}{l}\text { Materials } \\
\text { Proximity }\end{array}$ & $\begin{array}{l}\text { Near (haul } \\
\text { distance } \\
\text { between } \\
0-5 \mathrm{~km} \text { ) }\end{array}$ & $\begin{array}{c}\text { Average } \\
\text { (haul } \\
\text { distance } \\
\text { between } \\
5-10 \mathrm{~km} \text { ) }\end{array}$ & $\begin{array}{r}\text { Far (haul d } \\
\text { than }\end{array}$ & $\begin{array}{l}\text { ance greater } \\
0 \mathrm{~km})\end{array}$ \\
\hline 4 & $\begin{array}{l}\text { Traffic } \\
\text { Group }\end{array}$ & $\begin{array}{l}\text { Very light } \\
(<15 \text { vpd })\end{array}$ & $\begin{array}{l}\text { Light } \\
(15-30 \\
\text { vpd) }\end{array}$ & $\begin{array}{l}\text { Medium } \\
(30-50 \\
\text { vpd })\end{array}$ & $\begin{array}{c}\text { Heavy } \\
(>50 \mathrm{vpd})\end{array}$ \\
\hline 5 & $\begin{array}{l}\text { Drainage } \\
\text { condition }\end{array}$ & $\begin{array}{l}\text { Good } \\
\text { (rain don't } \\
\text { stand on } \\
\text { the road ) }\end{array}$ & $\begin{array}{c}\text { Fair ( } \\
\text { some } \\
\text { water on } \\
\text { the road } \\
\text { during } \\
\text { rain) }\end{array}$ & $\begin{array}{c}\text { Poor } \\
\text { (much } \\
\text { water on } \\
\text { the road } \\
\text { during } \\
\text { rain) }\end{array}$ & $\begin{array}{l}\text { Severe (no } \\
\text { functioning } \\
\text { drainage } \\
\text { system) }\end{array}$ \\
\hline 6 & $\begin{array}{l}\text { Shoulder } \\
\text { condition }\end{array}$ & $\begin{array}{l}\text { Good } \\
\text { (good } \\
\text { shape) }\end{array}$ & $\begin{array}{c}\text { Fair } \\
\text { (uneven } \\
\text { shape) }\end{array}$ & $\begin{array}{l}\text { Poor (poor } \\
\text { shape) }\end{array}$ & $\begin{array}{l}\text { Bad (does } \\
\text { not exist) }\end{array}$ \\
\hline 7 & $\begin{array}{l}\text { Surface } \\
\text { condition }\end{array}$ & $\begin{array}{c}\text { Good } \\
(<8 \mathrm{~m} / \mathrm{km} \\
\text { IRI })\end{array}$ & $\begin{array}{c}\text { Fair } \\
(9-14 \\
\mathrm{m} / \mathrm{km} \\
\text { IRI })\end{array}$ & $\begin{array}{c}\text { Poor } \\
(15-18 \\
\mathrm{m} / \mathrm{km} \mathrm{IRI})\end{array}$ & $\begin{array}{c}\text { Bad } \\
(>18 \mathrm{~m} / \mathrm{km} \\
\text { IRI })\end{array}$ \\
\hline
\end{tabular}

These parameters differ with those assessed in USA, which according to Shahin [4] are also seven and can be assessed visually, namely improper cross section, inadequate roadside drainage, corrugation, dust, potholes, ruts, and loose aggregate.

Of the seven parameters listed in Table 3, only road surface type, material proximity, traffic group, drainage condition, and shoulder condition can be readily visually observed with certain accuracy, but surface material rates of wearing and surface condition in terms of IRI are difficult to ascertain visually without special measuring instruments. Among the seven parameters only four are distress, the remaining three, that is traffic, surface type, and materials proximity are more or less part of road inventory.

The calculation of MCI is not user friendly as is being done by DROMAS, while that of PCI can be performed manually, by PCI computer program, or by 
entering distress data on Micro PAVER. DROMAS operational requirement does not reflect the real economic situation of Tanzania.

The TANROAD'S RMMS is mainly centralised at Head Quarter, with regional offices providing data to run it. The multi-criteria analysis used by TANROADS in prioritising maintenance and rehabilitation works might in the long run favour those regions with massive tourist attraction. The uses of HDM4 analysis tools do not advance the local knowledge in model building. Both RMS discussed has no room for private sector. Most of developed World RMS uses locally developed software and the structure of PMS reflect the level of economy and technology reached by these countries.

\section{Conclusions}

The paper has discussed the Tanzania PMS as typical PMS existing in subSahara Africa, and the following conclusion have been; 1) Maintenance cycle vary with the economic power together with quality of construction and appropriate maintenance responses, hence each country has to tailor the PMS to suit its level of economic and technology development, 2) There is a need for private sector involvement in running the PMS by letting them manage part of the gravel road network, 3) The PMS has to involve local experts and users at grass root level, devolving responsibility increases road agencies energy and gives people at all levels the incentive to find solutions, 4) An integrated PMS for all unsealed road in a country is paramount, regardless of who is overseeing the management operations. This will enhance the sharing of experience and improvement of PMS.

\section{References}

[1] Pinard, Mike I., Managing SADC Roads Agencies in the New Millennium: The Role of Road Asset Management Systems. Annual Roads Convention Proceedings. Good Roads for the Next Century, pp 138-148, 1999.

[2] Oliver, J.E., Basic road maintenance operations (Chapter 17). Topics in Highways; the Location, Design, Construction and Maintenance of Road Pavements. ed. C.A. O'Flaherty, Butterworth-Heinemann, Oxford, pp. 452-477, 2002.

[3] Underwood, Robin. T., Road Engineering Practice, MacMillan Education Australia PTY Ltd, pp 465 - 470, 1995.

[4] Shahin, M.Y., Pavement Management for Airports, Roads and Parking Lots, Chapman \& Hall, New York and London, pp. 7-27 \& 112-223, 1994.

[5] Draft TRH 22., Pavement Management System. Committee of State Road Authorities, Pretoria, South Africa, 1994.

[6] United Republic of Tanzania, Prime Minister's Office Regional Administration and Local Government, Annual district road inventory and condition survey and District road management system, 2004. 
[7] Schliessler, A., and Alberto B., Roads; A new Approach for Road Network Management and Conservation. United Nations Economic Commission for Latin America and Caribbean, Larrea Diseñadores e Impresores, Santiago, Chile, 1993.

[8] TANROADS $3^{\text {rd }}$ Quarter Progress Report 2009/2010 and PMORALG's Operational Plan for 2010/2011.

[9] Katula, J. and Toole, T., Road Management System-The development of the Road Mentor System in Tanzania. Proceedings of Annual Roads Convention, Dar es Salaam, Tanzania 2000. 